\title{
Obama Deception?: Empire, 'Postracism' and Hegemonic White Supremacy in the Campaign and Election of Barack Obama
}

\author{
TAMARI KITOSSA \\ Brock University
}

\begin{abstract}
The essay provides a socio-historical account of the role that hegemonic white supremacy played in the Presidential ascendancy of Barack Obama. I suggest that Obama crafted his political ontology to articulate a discourse of post-racism. Deploying a postmodern amorphous blackness he assuaged White anxiety about whether a Black president will seek to call in the lien African Americans have on the state and White US society for a more just society. By trading on the racial ambiguity of his biography in a country that demands certainty of racial lineage, his personage was made to affirm both the end of racism and the redundancy of anti-racist action. The result was a presidential campaign that traded on the hopes of African Americans and assuaged the anxieties of European Americans and others while propagating the interests of the ruling class and the military industrial complex.
\end{abstract}

Key Words: Obama, post-racism, racism, hegemonic, white supremacy, empire 


\section{Introduction}

Written a month and a half into Barack Obama's first term, the core elements of this paper were delivered as a lecture for African Heritage Month to a third year class on racism and anti-racism. My giving the lecture itself was unintended. It was a replacement for an invited colleague who had to cancel his appearance. In the months leading up to the election my colleague and I discussed, quite frequently, the policy implications of an Obama Presidency on US foreign policy and domestic relations. I expressed my concern and fascination during these conversations about the cult-like charisma driven preoccupation with Obama as the 'new Black'. I was fascinated by many of my family and friends who seemed to bestow mystical significance to Obama's biography/blackness as signs for/of change. Relatives, especially those in the US were caught up in the post-civil rights-ism euphoria. But I did not share this cheery view of Obama as a political actor. Not because I didn’t like him as a person, but rather because politics from the citizen's perspective is not an appropriate forum for sentiments such as "like" and "dislike".

Indeed, for the months leading up to the election I had numerous conversations with my colleague about the near unanimous suspension of critical judgment about Obama's locus in the machinery of the US's political and economic elite. With rare exception, I noticed Left blogs and news sites consistently took a wait and see attitude about whether Obama would rule differently than his predecessors. Whatever the case, race was explicit in ways it was not in previous presidential elections. African Heritage Month, too often given to romanticism, struck me as the 
most opportune moment to disrupt this uncritical celebration of how Obama's blackness was being articulated.

My colleague and I agreed that what was needed was a critical but not cynical analysis of Obama's platform and ways he deployed race and just equally how race was invested in the meanings imputed to his ostensibly progressive politics. After all, an aspirant for the most powerful political office of the most powerful country should not be regarded through a sentimental lens. Rather, the question of how sentiment played into the aspirations of those who favoured and disfavoured his candidacy and the extent to which Obama himself articulated a platform to suit these opposing forces were crucial for lucid and complex analysis that steered away from the facile. For us then, blackness and the discourse of "hope" were not grounds to grant Obama the benefit of doubt as to the possibility of economic and political reform and racial healing in the US. Maybe as Canadian men of African descent of a radical Left persuasion we felt little compunction that we were conceding to racism by virtue of a relentless critique of the first serious Black presidential contender. Indeed, based on the historical record, we knew both intuitively and concretely that Black people do not rise to positions of power and influence in the 
White world without conceding the necessity of sustaining hegemonic white supremacy. ${ }^{1}$ If

Obama became president of an imperially dominant USA, he too would be bound by the inertia of this historical fact. This fact, in the lead-up to the election seemed lost on many commentators and those in civil society who favoured his candidacy. Interestingly, those on the right saw clearly the issue of empire and presumed the essentialism that blackness equaled radicality feared the worst because of an Obama Presidency. Events since his inauguration have shown the fears of the latter unfounded.

But, aside from merely filling-in for a guest lecturer with whom I shared a similar perspective, there was another reason for me to deliver the talk during African Heritage Month: my son. A grade 12 student at the time I delivered the lecture, my son reacted with outrage in his English class when a White male classmate profligately and out of context used the word

\footnotetext{
${ }^{1}$ White supremacy is frequently obfuscated by its assignation to a violent and fringe element of Eurocentric societies. The binary opposition is not justified because it fails to recognize that White supremacy has morphed from mass dominative racism to aversive and meta-racism (ie., state-practiced white racism) (Kovel, 1971). Suggesting white supremacy is historically contingent but also historically continuous and systemic, Darden contends:

Unlike overt white supremacy which involves individual whites acting against individual blacks or other people of color, which may result in death, injury, or destruction of property and often involves a fringe element of white society, institutional white supremacy originates and operates by, and with the approval of established and respected forces in society (Darden, 2004, p. 6). Suggesting historical and normative reasons for maintaining the label white supremacy rather than white "privilege", Charles Mills posits white supremacy "has the semantic virtues of signaling the existence of a system run by, and in the interests of, whites - thereby pointing on its face toward a conceptualization in macroterms" [italics in original] (2003, p. 177). Vital to Mills' formulation is that white supremacy in the West was, because of the embarrassment of Nazi Germany and the poor example of Europeans at each other's throats in two major $20^{\text {th }}$ century wars, a facesaving modification in rhetoric. He notes, white supremacy: has changed from a dejure to a defacto form. The merely formal rejection of white supremacist principles will not suffice to transform the United States into a genuinely racially egalitarianism society, since the actual social values and enduring politico-economic structures will continue to reflect the history of white domination (Ibid).

Consistent with a systems rather than a solely micro or meso expression, Tim Wise identifies white supremacy as "the entire structure of American institutions, historically and still too often today" (Wise, 2009, p. 15).
} 
"nigger" in his discussion of To Kill a Mockingbird. Chastised by his teacher not to be shrill, my son remarked to his teacher and class that his White male classmate ought not to use the word. His reasons were twofold: first, his classmate lacked the wisdom to discern the economy of its use and to appreciate its historical burden. To his mind, it was White people who created the word as a label of derogation and domination of Black people so they should not be among those allowed to use it. Second, he argued, it appeared pleasure was being derived from its injudicious and uneconomical use. My son suggested he could not be certain his classmate was not disparaging him and other African descended people under the cover of literary freedom. The teacher's response: literature is license, and, besides, "What would Obama do?" Stopped cold in his tracks, the question presupposed for my son the answer - abide with forbearance the arrogance of others. No doubt, in the simple mind of his teacher, since my son is a "mongrel" like Mr. Obama and therefore contingently Black, he probably should not have taken offence in the first place.

As I paid more attention to how the debate about Mr. Obama was being taken up, I realized my son's teacher was not alone in the confidence that Obama's ascendancy signaled the denuement of the declining significance of race and hence the irrelevance of anti-racism. There seemed a "hopeful” Black, bi-racial, crypto-Muslim, Barack Obama for everyone: a veritable essential and inessential blackness. To some extent, these issues would have arisen even if Jesse Jackson or Al Sharpton were a breath away from the White House, though for sure how they would navigate competing racial desires in the public would differ. But, that it was Barack 
Obama and not them, suggests attention must be paid to how Obama crafted a narrative of race which enabled complex and multiple readings that drew on blackness as essential and inessential in a dialogic fashion. In this essay therefore, I do not assume the essential condition of blackness constitutes a politics of resistance to hegemonic white supremacy and that somehow Barack Obama betrays the proposition that blackness is a sine qua non for progressive politics. On the contrary, like the historic blocs familiar to Marxists, hegemonic white supremacy constitutes blackness as an oppositional form against which Black political elites must speak to White voters' fears of Black revenge. This essay thus offers a critique of Barack Obama's strategic deployment of race without the necessity of conceding he betrayed an essential politic associated with blackness in a hegemonic white supremacist society and world system. There is thus no effort to determine whether and to what extent Obama willingly supports hegemonic white supremacy. My objective is not to prove his intent but to show how he made use of available discourses to achieve political office. ${ }^{2}$

\section{Race and the Vote}

Barack Obama's presidential campaign was not inconsistent with hegemonic white supremacy in systemic terms. No president has thus far been elected without identifying with and

\footnotetext{
${ }^{2}$ Ford (2009), Eibach and Purdie-Vaughns (2009) and Peery and Baudenhausen (2009) have also examined how Mr. Obama deployed ambivalence and "post-racial" narratives of race in the election. However, these authors do not address themselves to white supremacy in any systematic fashion.
} 
propagating the interests of European Americans ${ }^{3}$ as a hegemonic bloc (Hacker, 2008). ${ }^{4}$ Unlike Obama's predecessors' campaigns there was no spectacle of the assorted anti-African American tropes: 'ghetto' welfare mothers, rapists (e.g. Willie Horton specters) and crime and drugs. In his campaign there was no spectacle of the assorted anti-African American tropes of previous US presidential campaigns: 'ghetto' welfare mothers, rapists (e.g. Willie Horton) and drug dealers. How then could his campaign have been consistent with hegemonic white supremacy? If it appears white supremacy did not in fact define his campaign has the US transcended the deep structuring of White racism in every facet of its institutions and civil society? If the US has transcended white supremacy why did Obama pitch his campaign toward neutralizing White

\footnotetext{
${ }^{3}$ The United States of America is NOT America and hence "United Statesians" is not uncommon in usage (Rousseau and Houdart, 2007) though I will not use it. America is divided into North and South continents joined by an isthmus. As such, these broad geographic regions contain a total of 22 countries which are not to be subordinated in nomenclature with the US's Monroe Doctrine of Manifest Destiny. As such, awkwardly but accurately, the citizens of the USA will be referred to as US citizens. I have, however, retained the terms African American and European American for ease of composition.

${ }^{4}$ There are many who would object to this interpretation. Brent Staples, for example assumes the nuance of Obama's speeches reflect the subtleties of a man who consciously refuses crass racial politics but instead bespeaks an ideal that transcends racial particularism (2009a; 2009b). Others such as Parker et al., (2009) readily assume racism was a ploy used by Hilary Clinton and John McCain, and it was, but not deployed by Barack Obama. The rejection of my thesis is implied in the work of Galen and Bodenhausen (2009; See also Ford, 2009; Eibach and Purdie-Vaughns, 2009). Consistent with the title of their essay, "Ambiguity and Ambivalence", their conclusion moves little beyond the certainty of ambiguity vis-a-vis how US society takes up the problematic of race connected to Obama:

As the number of multiracial people in the United States grows - people now have a prominent representative in Obama - we may well see changes in the way in the way we define race and its categories. On the other hand, we may not understand the nature and implications of these new distinctions any more than we understand the old ones we may be moving away from. Obama's success per se is unlikely to provide answers to questions about race that have eluded us thus far (p. 79).

The foregoing is unacceptable mystification that negates the "morphing' qualities of White racism (Duster, 2001) as elaborated in analytical accounts of "democratic racism", "new racism", "enlightened racism" and "racism 2.0". My contention throughout this essay is that despite Obama's references here are there to slavery and White oppression, the overarching thrust of his rhetoric of equality is in fact a mask for the defence of White protectionism (See Willhelm, 1994).
} 
anxiety? If after aiming to neutralize White anxiety, why did exit polls show that he garnered only $43.5 \%$ of White male and female voters and when White 18 to 29 are excluded, only $41 \%$ of Whites between 30 to 65 and older voted for him. This may not be the White racial defeat it appears, though. Given in all likelihood his appeal to hegemonic white supremacy brought him greater dividends than had he not overtly moved to assuage White anxiety about a Black man in the White House, the number of White voters could have fallen so disastrously low it would have offset the $95 \%$ African American vote, the $67 \%$ Latino vote and the $62 \%$ of Asian voters (CNN, 2008). Despite his defeat by White voters, Obama's Presidential victory is cast as a triumph of "post-racism". This is clearly not consistent with the facts, so how Barack Obama's presidential campaign and political ascendancy reconfigured the appearance of practical implications of hegemonic White supremacy requires explanation.

I will argue in this essay that, as in Dave Chappelle's hilarious skit about a blind Black man who is a white supremacist, the possibility of a Black American sustaining hegemonic white supremacy is a canard that overturns standard definitions of who can support hegemonic white supremacy. Chappelle's character gives us choices. We can 're-fence' the apparent anomaly, holding it in abeyance because it does not accord with established patterns of thought and practice (Allport, 1954, p. 23). We can reject the apparent anomaly, since it may be presumed blackness disqualifies a person from sustaining hegemonic white supremacy. Or we can develop a critique equal to the conditions it attempts to explain (see Smith citing Lenin, 2003, p. 314); which is to say that given systemic White racism, the 'order of things' makes racism an equal 


\begin{abstract}
${ }^{5}$ History furnishes multiple examples of individuals and select elites who have collaborated with the regimes of superior forces for a variety of complex reasons, not excluding duress. This collaboration may occur within a group, such as in the Americas where during chattel slave 'drivers' were of African descent. In a variety of colonial regimes such as the British Raj, Indians were used in the colonial repressive apparatus to suppress anti-colonial revolts. Lenni Brenner demonstrates there were Jews who collaborated with the Nazis (1983) and even Garvey held preliminary talks with the KKK. The case of the Buffalo Soldiers who fought to ethnically cleanse the US Midwest and indigenous Civilized Tribes who enslaved African Americans are two further interesting examples from the US (Katz, 1986). Recently, it has been shown that even the great Ghandi found cause for collaboration with white supremacy in South Africa: "Ghandi devoted his time, education, and talents to achieving legal superiority over the black natives; equality was only on his agenda when it included an opportunity to suppress blacks" (Singh and Watson, 2009, p. 14). In a more sophisticated way, where 'welfare' serves to simultaneously pacify and stigmatize the excluded and the useless (Garland, 1987; Willhelm, 1983, p. 254; Piven and Cloward, 1993), the state absorbs a coterie of the African American 'middle class' who would never be employed by private industry. This 'elite' is a small
\end{abstract}

group of black middle-class professionals [who] have been put on the public payroll to administer the many public assistance programs designed to assist this new urban underclass. The system represents a kind of 'welfare colonialism' says author's Michael Brown and Steven Erie, 'where blacks were called upon to administer their own state of dependence' (Rifkin, 2004, p. 77).

Whereas the Black middle-class, such as it is, dwindles as does the welfare state, the military arm of the state makes room for more Buffalo soldiers. Colin Powell, for instance, the most highly decorated US general since Eisenhower, played a key role in covering up the My Lai massacre of 1968 (Parry, 2009). He was National Security Adviser to George Bush Sr., when the US invaded Panama City to abduct Manuel Noriega and murder of 5000 of its people in 1989. As Joint Chiefs of Staff, he oversaw the first invasion of Iraq and famously lied to the United Nations, on pretext for a second and illegal invasion of Iraq, that Saddam Hussein possessed 'weapons of mass destruction'. Aside from Powell, domestic police forces also parallel the experience of Buffalo soldiers, though African American police officers are in a tendentious position vis-à-vis an internal occupying force in African American ghetto communities (Jones, 1973) and rejection from their White peers (Bolton and Feagin, 2004; Rafky, 1975). For example, attesting to the racism is an equal opportunity employer thesis, two of the three officers acquitted of killing Sean Bell, an unarmed New York man, in a hail of 50 bullets, were African American (Baker, 2009). An excellent elaboration of the Black comprador elite thesis is offered by Novick (2009): "We have moved beyond the 'house negro/field negro' distinction drawn by Malcolm X, to a distinction between Black overseers, managers and consiglieres of white property interests on the one hand, and Black lumpen, super-exploited and current, former and future prisoners on the other". 
and strategically appropriated the radical enterprise of anti-racism by deploying a postmodern amorphous blackness that undermined the need for anti-racism. On one hand he assuaged White anxiety about whether a Black president will seek to call in the lien African Americans have on the state and White US society. On the other hand, he propagated the belief that where Whites voted for him, this confirmed the triumphal defeat of hegemonic white supremacy.

In either case, by trading on his blackness his personage was made to affirm both the end of racism and the redundancy of anti-racist action (both of which, ironically, are belied by everyday white supremacist invective leveled against him). Through select and strategic claims of Black fraternity, Obama surreptitiously deployed anti-African American tropes that were passed off as pastoral concern for "his" people. In some ways, he extended a similar paternalistic narrative to the reproach of African leaders in his speech given in West African when he became President (Obama, 2009). The arguments are to be taken as a whole, aimed at unpacking Mr. Obama's white supremacist presidential campaign and to suggest its effects are more than symbolic. Mr. Obama's discourse on race, and his persistent 'colour blindness' even into his presidency, negates the oppression of African Americans while deepening their exploitation. To a significant extent, Obama deceived no one even if he intended. The deceit that blackness equals progressive change is built into the normative structure of how race is understood in the US. 


\section{Explaining Barack Obama's Political Ascendancy}

Accounts of Barack Obama's political ascendancy share one self-evident consensus: he is a Black man in the highest political office of a nation in which White people are economically, culturally, numerically and politically dominant. That the political ascendancy of no White president has had to be accounted for in racial terms, affirms the belief that White political overlordship is a norm for which no explanation is necessary. Toward this end, race does not explain all of Obama's ascendancy, but as suggested by Richard Dyer, rarely is race not a part of everything (1997). There is something impressive in the election of a man of African descent where typically African American legislators are regarded with suspicion when not under investigation by the FBI (Mann, 1995, p. 271-72).

The first account suggests Obama's political ascendancy is due to a crisis of legitimacy in the US economic and political system (Santos, 2008). The culmination of eight years of George W. Bush's regressive regime, eight years of Clintonian neo-Republicanism and 12 years of Reagan-Bush full-fledged neo-conservative ascendancy, US citizens were battered, bruised, fleeced and in need of a redemptive figure. The argument suggests the very legitimacy of the US liberal system required an outsider to the status quo who would restore confidence. One who inspired hope and was the embodiment of that quintessential US story: Horatio Alger ${ }^{6}$. Paradoxically, being epidermally associated with one of the most despised groups in US society, the political ontology of this insider-outsider would affirm the mistaken idea that the crisis of

\footnotetext{
${ }^{6}$ Obama describes his Alger-Booker T-esque story in his autobiography (2004).
} 
capitalist and state legitimacy is a function of minor systemic defects rather than structural contradictions in the US's economic and ideological system. It had bypassed many, except Trotskyists and others with Marxist tendencies, that regardless of Obama's racial outsiderness, his class interests brought him fully in accord with the ideology that undergirded capitalist and state crisis in the first place. That early in his term he would fill the seat of the Secretary of the Treasury with a Wall Street and Reserve Bank insider, Timothy Geithner, bespeaks his class allegiance or at least indebtedness to the financial elite. ${ }^{7}$

A second explanation is that Obama represented the alter-ego of one of the US's favoured tropes - the ubiquitous 'criminal-black-man' (Russell, 1997). A staple of the US's racist media system, Obama represented the 'criminal-black-man's' antithesis: the magic negro (Ehrenstein, 2007). This 'tropic' character, often the side-kick of the White hero or the conscience and spiritual guide of the White protagonist is of a special sort: cerebral, effete when not sexless and doting. In art as in life, the magic negro exists as $a$ shoulder, a body part like the hand that brings water, coffee, or cleans dinner plates, that Whites in the US can cry on or to. This shoulder, whose possessor is long-suffering, should after all understand pain. Depending on the time and place of course, perceivably smart men of African descent can, like their negative doppelganger, the 'criminal-black-man', be super 'negroes' and so always pose a threat. That is the magic

\footnotetext{
${ }^{7}$ Eliot Spitzer describes Ben Bernanke and Timothy Geitner's roles as Federal Reserve and Security and Exchange Commission executives who are complicit in the US and global financial crisis (Democracy Now, 2009).
} 
negro can also be The Spook Who Sat by the Door (Greenlee, 2002), masking compliance for the opportunity to strike at white supremacy and articulate a revolutionary Black politics.

The experience of African American Vietnam veterans, such Geronimo Pratt, who lent their guerilla and organizational know-how to radical Black liberation movements in the early 70's attests to this fear. The reigning order of distrust about Black men, therefore, assures the confidence in the magic negro is a fait accompli. Thus for US citizens of African descent, this trope requires self-monitoring because it is well-known the trust bestowed on them is a contingent one. Normatively, White US citizens are all too aware they benefit from the exploitation of African Americans and conservatives among them will undertake a variety of means to ferret out and destroy (disingenuous?) magic negroes. Conceivably, recurring threats to Obama's life and the extraordinary push from the Right (e.g., Rush Limbaugh) are less so calculated to deligitimate Obama as much as to enforce his compliance with hegemonic white supremacy. Indeed, the volume of death threats no doubt reflect the deep seated loathing of blackness but they are at the same time a push to remind him of his duty to maintain the racial status quo. Deftly extricating himself from his defense of Henry Louis Gates, over a beer at that, or dismissing President Jimmy Carter's contention that the anti-single payer health care reaction harbours racism (MSNBC.com, 2009), appear to affirm Obama's willingness to downplay the salience of racism in US society.

Related to explanation number two, is that at long last, the dreams of Martin Luther King Jr., and the Great Emancipator, Abraham Lincoln, have borne the full flower of democracy rather 
than the strange fruit of southern boughs. By this account, the election of Obama was a function of the civic and social maturity of US. The latter is perceived, more or less, as evidence that Gunnar Myrdal's observations of a dilemma and Malcolm X's visions of a nightmare are no more. Like Francis Fukuyama of the RAND Corporation's, ${ }^{8}$ End of History fame, the very militarist-statist think-tank deeply implicated in formulating Obama's education (RAND, 2009) and other policies, this perspective heralds the end of racism. Or at the very least as Santos suggests, Obama's election is "end of the struggle to end racism" (Santos, 2009). The latter differs little from the former given that the end of racism and the presumed emergence of the 'post-racial' society, consigns those who are White racism's victims and those who must struggle for racial equity as faceless, nameless and ultimately, useless anachronists. Propagated by Obama himself and others in the media, this claim heralded his election as both the end of racism and the messianic emergence of a new post-racial Republic in which anti-racism, and the antiracist, is politically superfluous (for critique of post-racism see: Pettigrew, 2009; Wise, 2009; Santos, 2008; Winant, 2001).

Finally, there is the power politics and the shadow government of global finance and elite political machinations perspective. This view is waved off contemptuously as "conspiracy

\footnotetext{
${ }^{8}$ RAND Corporation is derived from Project RAND (1942). It was originally a US Air Force strategic research group that conducted research and produce policy documents to guide the US's military ascendancy. Since the mid60's RAND's work has expanded into the social realm as its independence from the US Air Force was affirmed. Among other things, the world owes to RAND the internet; the US engagement in Vietnam; mutual assured destruction (MAD); Star Wars; the invasion of Iraq; policy interventions in the criminal justice, economic, educational and social realms; and the cult of numerical and rational calculus so pervasive in every facet contemporary life(see Abella, 2008).
} 
theory". Many would presume power politics has little to do with Mr. Obama's election since we all know that he raised the bulk of his presidential funding through the internet. Even if this is true, corporate and finance America have a well-organized and influential lobbying presence no amount of internet funding can match. Disparate individuals, no matter how much is collectively donated are too ideologically diffuse and disorganized to cohere into central lobbies that influence the political-economic and law-making process. Apart from their vote, which, as it appears can be stolen and their Commander in Chief selected by the Supreme Court, their central lobby is mass action and social movements which, problematically, cohere around select issues rather than an overall revolutionary reorganization of property and the means of production. The cant that 'Wall Street is too big to fail' reflects the dominance of finance capital over the organs of the state, in addition to the military that is wedded to it. A whole range of publicly traded commercial and military manufacturing corporations (e.g., Boeing, Carlisle Group, LockheedMartin, McDonell Douglas, Raytheon, Smith and Wesson etc) are the link between massive state military congressional appropriations and private banks. Barack Obama did not promise to wean the US off its post-World War II consensual myth that war-making and butter-making are synonymous (Melman, 1985).

In view of the interconnectedness and concentration of wealth and power among the ruling class and economic elite, it is not insignificant that while corporations could not at the time of his campaign make political donations, Obama drew some $40 \%$ of his campaign finance from well-heeled individuals in major banks, securities and other such enterprises (Kuhnhenn, 
2007). Aside from bankers and the wealthy whose interests Mr. Obama defends, though he must place priority on capitalism foremost, the bi-partisan choice of economic and political elites on his transition team and ultimately cabinet suggests the power politics view of his political ascendancy cannot be dismissed as mere conspiracy (Teichrib, 2009).

Where theory and explanation require distillation so that conciseness may be achieved, no effort to expose hidden dimensions of reality can be effectively achieved by foreclosure or emphasis on mono-causation. For this reason, I suggest many accounts of Obama's ascendancy, radical, or otherwise, have not effectively calibrated the effects of the social history of class, gender, and race with Obama's self-presentation and how he drew on this complex social history. Any coherent account of Obama's ascendancy must therefore employ some of the foregoing explanations. Thus, appreciating the uniqueness of his political ascendancy it is necessary to recognize these multiple trajectories in terms of a socio-history of the present. It is vital to consider the interconnected implications of: a deep civic desire for change (not transformation); a hegemonic White public ready to believe it had transcended racism and the struggle for racial justice (by vote!); a civil society devastated by 28 years of RepubliCrat policies that propelled the Horatio Alger-like candidacy of a brainy, racially mixed, non-threatening Black man into the White House; and a powerful elite with the resources to influence the political culture of the US, regardless of ballot democracy. While Obama's election eludes a single cause, this is not to say that race was not a salient feature in and through which this complex social history was played out. I turn now to account of the uniqueness of Barack Obama's political ascendancy 


\section{Primus Inter Pares: Race, Leadership and the 'First Among Equals'}

The political ascendency of Barack Obama to the highest and most powerful political office human society has known has no parallel in contemporary history. Antiquity furnishes the example of Septimus Severus (Davidson, 1987, p. 68), the North African nominated by the Roman Legions in York, England, to rule the Roman Empire; but, this is only to show that Obama was not the first African to be anointed emperor by power elites to lead the imperial machinery that dominates his racial kin and others. Lech Walesa and Nelson Mandela, two of the latter $20^{\text {th }}$ centuries most iconic political figures, rising like phoenixes from the ashes of apartheid and political repression may be tempting modern comparisons, but only superficially so. Obama, like these other men is an outsider to the hegemonic embodiment of power in their respective societies: Walesa in class terms and Mandela in racial terms. Other political leaders of the $20^{\text {th }}$ century who threw off the shackles of direct colonialism, only to find themselves laid prone by the Western economic Mafiosi - the Bretton Woods Institutions - or battling, as the Vietnamese Ho Chih Min did, against a protracted and genocidal Franco-US siege, bear superficial resemblance to Obama in the one area that counts: the Western raciological belief that they are untermenschen (see Simon-Aaron, 2008; Mills, 2006).

Compared to Septimus Severus or Walesa, however, Obama is unique. On his person is marked the "socio-genic" "fact of blackness", a condition that, in the "epidermal schema" established by Europe, must be explained away (Fanon, 1967). In spite of colour similarities, Septimus Severus is not a fit historical comparator to Obama. In Severus's case, "race" as we 
know it today had very different coordinates: citizen vs barbarian and Mediterranean (literally, middle earth) vs negative morally determined geographic polarities (northerners were seen as frigid and southerners were seen as having hot constitutions.) (Sherwin-White, 1967;

Jordan,1977). These cultural-geographic-citizenship determinants, though they secondarily ascribed moral value to skin colour, were the coordinates by which Aristotle would determine natural born slaves (Aristotle, 1958, p. 13-14) and Galen would develop the first "scientific" racial classification system contingent on a raciological moral geography (Brackman, 1979, p. 134-135; Siegel, 1968; Green, 1951). The latter, would be picked up by Buffon, Blumenbach, de Gabineau, Linneaus and Kant ${ }^{9}$, inter alia, in various iterations of European Enlightenment raciological thought (Eze, 1995; Gould, 1981; Poliakov, 1974).

Politically, while like Obama, Severus was sought-out by the power elite of his time, Severus differs fundamentally in that Rome was not a popular democracy in which the sovereign required the legitimacy of the masses. To this end, the politics of race relative to the legitimacy of the right to rule was a non-starter. Severus ruled, not because the political conditions required him to demonstrate his allegiance to the White Roman proletariat versus his North African kin, but because as a general in the Roman army he was the embodiment of the empire and this required no further proof. Obama's situation is considerably more complex because the racial landscape in the US encodes material opposition to White supremacy onto the bodies of the

\footnotetext{
${ }^{9}$ Comte de George-Louis Leclerc Buffon 1707-1788), Carolus Linneaus (1707-1778), Kant (1724-1804), Johann Freidrich Blumenbach (1752-1840), and Joseph Arthur Comte de Gobineau (1816-1882). For elaboration and qualification on their specific contributions racial thought see Ani (1994) and Gould (1981).
} 
racial "other", but in particular African Americans. Thus, Obama had to and will always have to prove his allegiance to white supremacy and to US Empire (see Offen, 2009). In spite of the appearance Obama is compelled to maintain the war machine he inherited from George W. Bush, there is every evidence, that Obama embodies the aspirations of empire as much as Septimus Severus (see Lutz, 2009). Despite his Nobel Peace Prize, for what it is worth, ${ }^{10}$ Obama has upheld and even extended key elements of the security and war architecture of the Bush Doctrine on 'terrorism': notably drone attacks in Pakistan and maintaining the domestic eavesdropping and no-knock powers of the state.

Obviously, the ontological fact of blackness in addition to the aforementioned existential fact of radical political struggle in Poland, exclude whatever remote comparisons can be made between Obama and Walesa. Obama may certainly have dappled in the Civil Rights struggle, listened to Kwame Toure and even sported an afro (Obama, 2004), but by no means did Civil Rightists transform US society and catapult African Americans into political overlordship in the state bureaucracy though their influence certainly modified the culture. Blackness in a white

\footnotetext{
${ }^{10}$ The merits of the Nobel Peace Prize were long ago doubted when the committee co-awarded the prize to Henry Kissinger (USA Secretary of State) and Le Duc Tho (Vietminh co-founder) for their respective roles in negotiating the "end" of the US war against North Vietnam (Spartacus Educational, 2009). Le Duc Tho, confronted with the duplicity of the Nixon administration declined his award, however. Despite his role as "peace-maker", Kissinger played a key role as Secretary of State in the destruction of Vietnam. Interestingly the same year of his award, he played a key role in the deposition of Salvador Allende, ushering in the brutal regime of Augusto Pinochet (Klein, 2008). Quite the Malthusian, in his "National Security Memorandum 200", Kissinger suggested Third World peoples, if their population went unchecked, would pose grave problems for the US in the future as well as outstrip their own food supply. Despite advocating for food security and the rights of women, the document's priority is developing a neo-liberal architecture. Thus he proclaimed, in contradistinction to the Geneva Convention on Genocide, "In addition to creating the climate for fertility decline... it is essential to provide safe and effective techniques for controlling fertility." (Kissinger, 1974).
} 
supremacist society delimited that possibility, except where the state made expedient accommodations (Willhelm, 1983:254) or in extreme cases "neutralized" African American leadership that would not be bought (Churchill and Vander Wall, 2002). In short, Walesa was a White man in a largely homogenous ethnic Polish country. Importantly, this fact excluded political appeals on his part to the lowest racist common denominator. This is not to say that class does not also have racial coordinates. Chaikh Anta Diop reminds us that:

In 1849, a professor at the Sorbonne wrote in a propaganda brochure against the 'Reds,' i.e., the Socialists: 'A red is not a man, he is red...he is not a moral being, intelligent and free like you and me...He is a fallen and degenerate being. Besides, he wears on his face the sign of this degradation. A despondent, besotted physiognomy, without expression, dull eyes, mobile and evasive like those of a pig, gross features, without harmony, a low forehead...his mouth mute and insignificant like that of an ass (1991, p. 128).

Where skin colour is coordinated with class inequality, this fusion produces a caste structure both real and symbolic. The effect of this dynamic is to produce a fusion of caste, class and race that is difficult to disentangle. Most certainly the overdeterminacy of race in the United States is a reality that symbolically, when not in reality, fuses sub/proletarianism as a "fact of blackness" regardless of what class African Americans are in (Cox, 1970; Willhelm, 1980).

Indeed, in the Rage of a Privileged Class (1993) Ellis Cose noted the mental anguish and negative systolic effect white supremacy had on the Black 'middle class' in the US. Because 
caste in the US reflects the concrete reality of White racial domination, this fusion produces a racial caste character to class relations. Knowing fully-well this fusion was built into the fabric of the nation by its founders and deepened all the more by the state, career politicians orient their rhetoric and practices toward maintaining hegemonic white supremacy. I suggest this dynamic only becomes substantively in question when that career politician is of African descent. In that instance declarations of which side of the racial caste-class-race fusion one is on is one demanded by the White caste. Indeed, where "legitimacy is the belief of the populace and the elites that [their] rule is proper and valid, [and] that the political world is as it should be" (Tainter, 2009, p. 27) the race of political figures plus their iterations requires sustaining the concrete interests of the dominant White group at the expense of "Others".

Given the racial politics of South Africa, Mandela may have more comparative resonance with Obama than Walesa only in that his person signifies the legacy of White over Black racial domination as opposed to the intra-racial fratricide evident in one Western power or another trudging through Poland over hundreds of years (culminating, of course, in German occupation). This resonance is vital given that as the White racial franchise was expanded in the latter half of the $20^{\text {th }}$ century to include the formerly stigmatized Irish Italians, Greeks and Jews, the effect has been a symbolic homogenizing of the racial "Other" (Deliovsky, 2010; Jacobson, 1999; Brodkin, 1998). Having spent 27 years in prison for his commitment to abolish apartheid, though his presidency ultimately failed in respect of abolishing economic apartheid, Mandela was virtually guaranteed office because Africans are in the majority and the White minority had no moral 
authority to lead. In spite of this central biographical distinction between the two men and the vast demographic difference between the two USA's, Mandela, like Obama, had to appeal to global white supremacist anxiety by crafting a tepid form of "anti-racism" curiously called "a non-racial South Africa". The similarity in their political discourse, which for Obama is framed as a "post-racial society", masks, however, a substantive and preponderant difference. This fact makes the election and presidency of Barack Obama a distinct historical fact. Unlike Mandela, Obama had to appeal to a White majority, in a capitalist and imperialist White settler colonial society that has the most destructive military capability the world has yet known. It is thus of consequence that Mandela was compelled to accept as a condition of his release and later presidency, that an African led South Africa under his leadership would dismantle its nuclear military program (since 1967 until the end of Apartheid in South Africa, South Africa and Israel jointly shared ballistic and nuclear development secrets, see Adams, 1984, pp. 23, 166-186).

How Obama, the first Black president of a normatively white supremacist society that is arrogantly imperial and necrotically nuclear, was elected in such an electrifying caste-class-race landscape is as important as the many reasons why. No doubt the world is better off with one less nuclear state. Yet, that the US, the only nuclear power to detonate nuclear devices in war, twice, against a non-White people is a crime against humanity not to be ignored. Even now, in its current unlawful adventure campaigns in Afghanistan and Iraq, the US has unilaterally rewritten the rules of war. As it does so, it whimsically rewrites the rule on captives of war and is profligate in its use of non-sanctioned depleted uranium and white phosphorous bombs (Daily 
Mail, 2009; Eyre, 2009). And, as if destructive capability can be dated, the US four star General Kevin Chilton demands greater maintenance capabilities while developing nimble nuclear weapons designed to support the US 21st century military needs (Wright, 2009). Why is Obama trusted whereas Mandela was not? Mandela made no offer to extend White and imperial power, whereas Obama, embodying the "new racism" will be silent to the oppression of African Americans, continuing to fill the prisons and death row with their ranks, while they, comprising $1 / 3$ of the US forces, are marched off to die defending pipe-lines and corrupt narco-governments. Obama, as the first Black emperor of the US, “...represents an expansion of war and the power of empire" (Santos, 2008), the very forces Martin Luther King, Jr., and his own Rev. Jeremiah Wright decried for murder abroad and deprivation at home.

\section{What Racial Difference Makes When Electing a President: Race, Memory, and National Culture}

The French scarcely bother to dote on the fact that their President is the son of Jewish immigrants. Given the tragic history of Jews in France, Sarkozy's Presidency is clearly momentous and very likely a first for France. If indeed he is the first Jewish President of France, the French have come second to the English. The English haven't repeated the feat of Desmond Disraeli as Prime Minister (1868, 1874-1880), and if they have the suppression of this knowledge is a rule that proves the exception - race matters most when the executive leader is not epidermally White. That the French have thought it wise to take Sarkozy's election for what 
it is, a politician who must be compelled to be responsive to working class people (including the underemployed and the unemployed) and France's déclassé ghetto reservation (for whom no work exists) is instructive. In part, the issue here is that Sarkozy did not formulate his political ontology in accord with his Jewish background. A vote for him was not a vote against antiJewish hatred any more than it was a rapprochement between Christian and Jewish French citizens; to suggest otherwise would have been denounced as facile political opportunism and naïveté on the part of French voters. Indeed, the election of a variety of women leaders, at one point or another all labeled "Iron Lady": Golda Meir (Israel, elected in 1969-1974), Margaret Thatcher (UK, 1979-1990 ), Indira Ghandi (elected 1966-1977, 1980-1984) and Benazir Bhutto (elected 1988-1990, 1993-1996), with the exception of Meir, had no appreciable positive impact on the lives of women in their countries; and, indeed, in the case of Thatcher's TINA (there is no alternative), women suffered appreciably from the retrenchment of the welfare state. In much the same way throughout this essay, I suggest the Presidency of Barack Obama will hurt African Americans. Not just by the 'Huxtable effect' where White Americans will see in him the triumph of Affirmative Action and hence its redundancy (Jhally, 1992). But also, that an Obama Presidency will explicitly defend the material interests of the ruling class and their elites and the White populace.

Obviously, neither in the conduct of Obama or that of the US's citizens was the French example evident. Ironically, the French among others around the world greeted the Obama Presidency with sigh of relief that the truculent Bush regime was over, and, they congratulated 
the American citizenry on their long-awaited maturity to see beyond race in electing a man of African descent as its President. If electing a man of African descent indicates political maturity, one may well wonder when the French will elect a North African or a Senegalese to its Presidential Office! Indeed, around the world a chorus of cheers greeted the news of November 4, 2008; so much that one might reasonably expect a bumper crop of male babies to be born 9 months later carrying his name. If this prospect seems ridiculous, then it is no more ridiculous to contend that Obama's election will spur a spate of African American Presidential hopefuls or encourage White Americans to be less racist; after all, like the proverbial Black "friend," White Americans did vote a Black American into office.

In Canada, polite opinion was in accord in wishing Bush a speedy adieu while expressing hopefulness an Obama administration will be a fresh start for the US and the world. Canadians like to feel themselves akin to the US, often using such platitudes as 'friend', 'family', and 'neighbour' if only to recharacterize Canadian integration into the US sphere of influence as being a relationship of equals. As if to underscore nation-to-nation familial ties, much was made of Obama's family connections in Oakville, Ontario. The hope was not only that the US would elect a President who fit with the Canadian mythos of philosopher king, who spoke softly but carried a big stick in international matters, but also a sincere wish that in choosing their next executive leader, the US's citizenry would break with its legacy of racism. The latter is a point many Canadians believe they have achieved through a formal policy of multiculturalism though the empirical evidence belies this. 
Like the Canadians, the French, and others around the world, many US citizens were enamored with this highly accomplished and charismatic man during the election campaign. To many, the election of Barack Obama represents a watershed in US racial politics (ie., the demise of white supremacy) because this could only have been possible if Black, White and other US citizens united to overcome their past of brutal racial antagonism. This simplistic notion reflects, universally, White people's weariness about 'race talk' regarding the continued significance of the colour line into the $21^{\text {st }}$ century. Indeed, as Houston Baker points out, many an Ivy League African American professor, having betrayed Dr. King's legacy, widely propagated the notion that "race" has lost its significance (Baker, 2008; see Wilson, 1978). This weariness in turn leads to a desire to grasp at any straw that would appear to confirm the redundancy of 'race talk' and anti-racist activism. Here, a hegemonic, formalistic, and romantic narrative of the civil rights movement as primarily an African American demand for desegregation, that is, epidermal political equality rather than substantive economic democracy, is the preferred imagery against which the election of Barack Obama is judged.

Certainly, there is something to celebrate in the election of a man of African descent in a country whose constitution decreed, by inference, Africans counted 3/5 toward the enumeration for taxation and the apportionment of Representatives (US Con. S.2, Para.3). There is much to celebrate, it would appear also, when progress is measured by the apparent post-1960's quietude of African Americans, the absence of water canon, police dogs, truncheons, paddy wagons and lynchings. The absence of these symbols of brutality and exploitation, however, do not so much 
reflect rapprochement as they do the state's successful twin-pronged response - extension of legal rights and the full destructive weight of the state on Black political rebellion - to African American agitation for jobs, economic equality, and full citizenship (Willhelm, 1983). Importantly, what adds to the appearance of rapprochement is the White working class's tacit agreement to leave the work of violence and repression to the state; although sporadic individual White racial violence and the 1960's White vigilantism that marked the aftermath of Katrina indicate otherwise (Wise, 2009, pp. 68-72). There is a fundamental preference to misunderstand the inextricable entwining of white supremacy with transformations in the technification of the capitalist mode of production, where formalism is celebrated as substantive social transformation. If this is so, reality produces ideological forms that are taken as the essence of reality (Mepham, 1979, p. 143). The election of Barack Obama is just such an ideological obfuscation of continuing and worsening reality for African Americans (Muhammad and Ehrenreich, 2009) and of course others around the world subject to US militarism. Advanced reflections on this state of affairs was likely overshadowed by the media's Obama-mania drive

\section{Mongrel in the White House: The Post-Racial President}

In so highly race conscious a society as the US, who would not find it disarming that its first recognized Black President should share publicly, in a jocular manner, that he prefers to adopt a dog for his daughters who, like himself, is a mongrel or a mutt (Gardner, 2008). Of course, for those whose social history is one in which the "one drop" rule prevailed to determine 
social caste and reflected abject sexual domination of Black women by White men and the lynching of Black men who married or cavorted with White women, the humour may be lost on them. Indeed, to make light of his "mongrelization" and to ignore its differential historical facticity, is, in view of white supremacy in the US, to attribute transcendence and maturity on the part of the White public and, of course, forbearance on the part of African Americans.

It is consequentially important, that there is little outcry today about the perpetuation of this eugenics impulse in the contemporary US relative to poor African American, and to a lesser extent Latina, Native American, and even poor White women (Roberts, 1992, p. 1961). So, far from a passing moment of humour, Obama used his own biography, not in a revolutionary way but as an ideological sociology of the self to demonstrate the choice of narrative of the nation he would align himself with. This narrative, a hegemonic narration of the (White) nation, is one in which radical stories are structurally excluded from consciousness and false ethical stances on racism are interpolated. I suggest that in crafting himself as the quintessential post-modern US subject, Barack Obama is able to deflect White criticisms that would otherwise doom an African American politician committed to revolutionary politics. I will now critically elaborate the false ethical complementarity Barack Obama drew between racism and anti-racism with an examination of his Philadelphia speech on race (and class) in the US. 


\section{Obama's Post-Racial Society: No Place for Racists or Anti-Racists}

The concept of post-Fordism or post-industrial clearly indicates the capitalist mode of production in the west has undergone specific transformations resulting from technology and overproduction, both of which have profoundly affected social relations. Self-evidently as well, this transformation in productive relations is marked by a transformation of elements of the working class being made déclassé; redundant, effectively, to the needs of capitalism (Willhelm, 1970). Whereas the materialist analysis of social relations presupposes transformation is determined by specified factors, what factors are suggestive transformation to a post-racial society? Presumably, the absence of mass movements oriented to challenging white power and the existence of formal juridical equality are but two factors. A third is whether non-state sanctioned white supremacist behaviour has been eradicated. In this formulation racism is hived off from social relations of production and is seen as ancillary to the facts of capitalist social relations of production. As such, racism is regarded as no more than a subordinate problem, one of sentiment, of prejudice, that can be transcended. So whereas technology, overproduction and falling rates of profit in the midst of wealth concentration are causes for transformation in social relations, it is assumed formal expressions which appear to transcend (eg., electing a Black president) racism are suggestive of the end of racism.

Fundamentally, the discourse of a post-racial society is about the redundancy of radical Left forms of political expression and socio-economic demands articulated from the vantage point of racial justice. The central plank of the discourse of 'post-racism' is not that it denies 
racism exists. Obama himself admits the issue by approvingly citing Faulkner, but shortly thereafter does violence to the author's radical aphorism that "The past isn't dead and buried" (Obama, 2008). Obama's discourse assumes race is declining in significance and obviously and along with it so too is racism's virulence. For example, Obama contended “...we won commanding victories in states with some of the whitest populations in the country. [And,] [i]n South Carolina, where the Confederate Flag still flies, we built a powerful coalition of African Americans and White Americans" [my italics] (Obama, 2008). That Obama touted cross-racial solidarity negates that he strategically deployed blackness as a sop to the White voter: a vote in his favour is a vote against racism. This point is well made by Michael Novick who points out: "Supporting Obama allows people who are not prepared to acknowledge or break with the system of white supremacy and settler colonial empire the ability to feel that they are color-blind and have transcended racism" (2008; see also Butler, 2008).

The post-racial discourse assumes that symbolic expressions, such as the Confederate Flag, are mild holdovers from yesteryear and that its acceptance stands alongside a widespread moral repugnance against overt racism. Indeed, "proving" racism has become increasingly difficult. As Derrick Bell points out, “...the very absence of visible signs of discrimination creates an atmosphere of racial neutrality and encourages whites to believe that racism is a thing of the past" (1992). Not only did the discourse make an explicit moral distinction between symbolic (aversive) and manifest (dominative) expressions of racism, it implies also that antiracism is specious militancy that is out of step with the times. Effectively, a moral equivalence is 
drawn between racism and anti-racism. One important consequence is that it inverts reality, suggesting that policies such as Affirmative Action do little but distort the labour market. Most white people would agree that racism is bad, even if, like Obama, they accept the Confederate Flag as other than evidentiary affirmation that dominative racism is being legitimated. They may well accept the Confederate Flag on public buildings, stickers on trucks and flag poles in front yards for the very same reasons they would object to Nazi flags so prominently displayed: as a matter of liberal democratic juridical equality and free speech one is acceptable and the other not. If, in the South, "a powerful coalition of African American and White Americans" can be built, obviously the legacy of domination and intimidation the Confederate Flag represents is 'dead and buried'. Accordingly, those Whites who hold racist views, who transition from aversion to prejudice, or who transition from prejudice to dominative racism (physical acts of aggression) without justification are imagined as atavistic. Admittedly in the "new" racial dispensation, the "old" US lingers on. Seen as atavists out-of-step with the tune of a cosmopolitan global society founded on 'diversity' and trade and free enterprise (at the barrel of a gun, or preferably, with the IMF's equivalent, structural adjustment), overt racists are shown up as retrograde bumpkins who know or care little for the changed international context in which the US must assert its dominance. Undaunted by ridicule, record breaking gun and ammunition sales is the post-election opening salvo of the solidly Republican states (Debusmann, 2009). In such states, it is most feared that Obama's election signals the triumph of racial democracy, will usher in socialism and it is suspected that the man is a crypto-Muslim 
(Wise, 2009; Butler, 2008). Because in his victory speech, Obama reminded his fellow citizens that he is President to them all, especially those who in the hall at McCain's concession speech openly referred to him as a "nigger" and wished him a speedy death, the requirement for such a reminder is evidence that a wide and even opposed cross-sections of US society believe both the Jordan and Rubicon were crossed in the single instance of electing a man whose father was African. But, inasmuch as the atavistic racist is censured in theory, there are imagined to be reasonable limitations for denouncing White racism.

From the firm establishment of racial slavery $\left(17^{\text {th }}\right.$ century) to the present, 'hyper' Black masculinity has become a thickly encrusted and routine motif in US popular culture (Stabile, 20076; Rome, 2004; Hutchinson, 1996). Indeed, Barack Obama acknowledge this fact when he observed, “... my white grandmother - a woman who helped raise me, a woman who sacrificed again and again for me, a woman who loves me as much as she loves anything in this world, [is also]... a woman who once confessed her fear of black men who passed by her on the street..." (Obama, 2008). This is an admission that routine demonization of African American men is as ‘American' as apple pie. If, as Jesse Jackson once admitted that he unconsciously crossed the street when he was walking in the direction of a group of young African American men, then Obama's disclosure tells us little about his grandmother and more about the national culture that holds this image of the 'criminal-black-man' as axiomatic. The irony of this truth-beyondquestion is not just that it propagates racism toward African Americans, but precisely because it is beyond question, therefore not racist in the minds of many, is what makes it one of the US's 
penultimate racist expressions - creating a culture of hegemonic white supremacy (see Willhelm, 1983, p. 283).

If overt racism is seen as passé and where racism articulates itself as national culture, liberal Whites, and Obama, would concur that the 'dangerousness' of some African Americans justifies fear and safeguards against the purported probability of harm (Rome, 2004; Stabile, 2006). By this measure, Bernard Goetz's preemptive shooting of four “menacing” African American youth on a New York subway train aroused great public sympathy and support among Whites (Williams, 1994:159). The assumption that "preemptive self-defence", even when racist sentiments are expressed, is not itself racist, was given full expression in the aftermath of hurricane Katrina. Tim Wise shows that wide-spread, and later unsubstantiated, rumours that African American men were looting and raping White women motivated the residents of White enclaves to stockpile a variety of weapons (2009, p. 69). The White community "militia" of Algiers Point was credited with shooting at least 11 African American men. Some of the White "militiamen" cheerfully admitting they were "out to wage a race war" and that they wanted the opportunity to "hunt black people". Significantly, Wise reports, "no one has been punished for these crimes... [and] no official investigation by law enforcement has occurred at all” (p. 72). ${ }^{11}$ If the words of Obama can be counted on, we can assume "preemptive self-defence", as much as the Confederate Flag, will be excluded from the category of atavistic racism:

\footnotetext{
${ }^{11}$ Suggestive of a historical pattern of unaccountability, Sidney Willhelm reports that in the Cleveland uprising of 1968, White vigilantes were active in the killing of African Americans (1983, p. 257).
} 


\author{
Most working - and - middle-class Americans don't feel that they have been \\ particularly privileged by their race ${ }^{12} \ldots[\mathrm{W}]$ hen they're told their fears about \\ crime in urban neighborhoods are somehow prejudiced, resentment builds over \\ time...to wish away the resentments of white Americans, to label them as \\ misguided even racist, without recognizing they are grounded in legitimate
}

\begin{abstract}
${ }^{12}$ European American citizens to whom Obama refers may not feel privileged but present and historical facts bear out that they are indeed psychologically and materially privileged, and at the expense of African Americans. Discriminatory arrest, imprisonment and conviction records that disproportionately delimit the life opportunities of African Americans are legion and have long been noted (Dubois, 1899, p. 284; Sellin, 1935, pp. 214-216; Bonger, 1969, p. 43; Sutherland, 1955, p. 139; McHugh, 1978, p. 62). Recently, consistent with a century of research into racial discrimination, Deirdre Royster demonstrated that White social networks constitute a cordon sanitaire against African American working class males gaining entry to the working class job market (2007). Devah Pager also shows that young African American men without criminal records fared no better than young White men with criminal records in attaining job search call-backs (2007). In October, 2009, the jobless rate for African American men (16-24) was 3 times the national average at 34.5\%, while for African American women (16-24) the jobless rate was $26.5 \%$ versus a national average of $15.4 \%$ (Haynes, 2009). The work of Sidney Willhelm (1970) and subsequently Jeremy Rifkin (2004) suggest technification of the capitalist economy, having both functional independence and dynamic interaction with racist social relations of production, has been extruding African United Americans from US economy since the mass use of the steam engine in agriculture. Technification of factory production and the rise of the computer over the last 40 years radically magnifies the expulsion of African Americans from the formal economy with various attendant social maladaptations presumed, erroneously, to be a function of an 'underclass' 'culture of poverty'. The latter has no scope to countenance the dynamic interaction between technology and White racism (see Wilson, 1987). Demonstrating the independent and dynamic interaction effects of technology and racism, Rifkin notes that between 1957 and 1964, the period in which African Americans are presumed to have made great economic strides, "manufacturing output doubled, while the number of blue collar jobs fell by 3 percent" (2004:75). But, as a consequence of White trade union racist social closure and the technological extrusion of Black labour, of Chrysler's skilled workers African United Americans numbered 24 out of 7,425, while they numbered 67 of GM's 11,000 skilled workers. As a consequence of the radical transformation of the economy and regressive class and race wealth transfers, in 2009 the Black unemployment...[was]...14.7 percent, compared to 8.7 for whites" (Muhammad and Ehrenreich, 2009). Such as it is, given it is insecurely ensconced in the private sector, the African American middle class is precariously perched to suffer most immediately the effects of recessions, such that prior to the recent crisis " 33 percent of the black middle class was already in danger of falling out of the middle class at the start of the recession" (Muhammad and Ehrenreich, 2009). Poverty and unemployment among African Americans, Latinos and Native Americans runs twice that for White Americans (Rivera et al., 2009, p. V; Muhammad, 2009, p. 6). In all, despite Obama's cheery claims of racial solidarity evident in his campaign, "what the whites often don't realize, [and evidently, given Obama's imprimatur, might not care to], is that while they are in a recession, blacks are in a depression" (cited in Rifkin, 2004, p. 78): depression that, under capitalism, will be permanent.
\end{abstract}


concerns - this too widens the racial divide, and blocks the path to understanding (Obama, 2008).

By this reasoning then, White racism is rational and worse yet, by progressive standards, can no longer be presumed to even fall under the negative characterization of racism because it is deemed 'reasonable' (Armour, 1994, p. 788; Williams, 1994, p. 159).

While evidently the atavistic racist has no place in a post-racial society, scope must be made not to confuse atavism with White resentment. To do otherwise, according to Obama, is to assent to a widening of the racial divide, and, as a consequence, to mischaracterize the "true" manifestation of White racism (eg., unjustified expressions of White racism). Whereas the atavistic racist can be explained away, no such accommodation is made to the anti-racist. The point, according to 'post racism', is not to deny the necessity for some form of anti-racism, because of course there is an admission of the persistence of atavistic racism. Rather, according to the post-racial discourse, the anti-racist, who is embodied in the eyes of Obama as the likes of Rev. Jeremiah Wright, who express "a profoundly distorted view of this country - a view that sees white racism as endemic, and elevates what is wrong with America above all that we know is right with America" (Ibid). The anti-racists' views on America are wrong because they do not express all there is about the US and their timing “...is not only wrong but divisive....at a time when we need unity" (Ibid). The problems that beset the US: two wars, economic collapse, "terrorism", health care crisis, and climate change are "...neither black nor white or Latino or Asian, but rather problems that confront us all" (Ibid). The unsubstantiated assumptions here are 
that, inter alia, Black political struggle is unnecessarily divisive, presuming there is a time when it will not be.

In castigating Reverend Wright for his critique of the US's domestic and foreign policy as “...divisive at a time when we need unity..." (Ibid), Obama suggests "black anger", though justifiable in calling attention to the civil and political defects that arise from an "unfinished" Constitution, "often proved counterproductive" (Ibid). Without ever explicitly saying what made Black anger counterproductive, we are left to infer from Obama that the cardinal sin of antiracists like Reverend Wright is a failure of religious and secular faith in secular progressivism: ...I have asserted a firm conviction... rooted in my faith in God and my faith in the American people - that working together we can move beyond some of our old racial wounds, and that in fact we have no choice if we are to continue on the path of a more perfect union (Ibid).

Progressing toward this "perfect union", of course, Whites must admit “...current incidents of discrimination, while less overt than in the past - are real and must be addressed" [my italics] (Ibid). But, White "resentment", evidently not having as its objective a requirement that the state and White Americans live up to their social responsibilities, regression need not be recognized since the presumptive decrease of "discrimination" proves the point of racial progress. By this logic, Black anger though, counterproductive in its refusal to have faith in White America's 'less overt" racism, walks a thin line of legitimacy that fails to admit Obama's political ontology. 
Meaning, Obama's political ascendency is evidence of racial progress and Black America should agree with this.

Toward this end, and commenting that the error of Reverend Wright is not in pointing out racism, but

[i]t's that he spoke as if our society was static; as if no progress has been made; as if this country - a country that has made it possible for one of his own members to run for the highest office in the land and build a coalition between white and black; Latino and Asian, rich and poor, young and old - is still irrevocably bound to a tragic past. (Ibid)

The significance of Obama's remark here rests on two fronts: race and class, both of which aim to negate the material basis for antagonism in US society. Implying his political ontology fulfills Dr. Martin Luther King's dream, Obama suggests that with the miraculous solidarity of rich and poor and Black and White alike in campaign, US citizens have come to grips with their tragic past of inequality. As such, the prospect is that the US will fulfill the ideals of its founders. This proposition neglects that the Founding Fathers explicitly fashioned a constitution that would protect the rights of private property over the mischief that is democracy. Alexander Hamilton made this clear: "[it is] the good will of most men of property in the several states who wish a government of the union of men to protect them against domestic violence and the depredations which the democratic spirit is apt to make on property" (cited in Mandel, 1994, p. 8). Further, it is instructive as Mandel observed, this sentiment was translated into law through Article 1 
section of the US Constitution: "No State shall..make any Thing but gold and silver Coin a tender in Payment of Debts: [or] pass any..Law impairing the Obligation of Contracts" (Ibid, p. 9). The central aim of this law was to prevent indebted farmers, with necessary right of suffrage guaranteed by property, from using their vote to compel legislatures to effectively achieve the equal measure to the contemporary "bailout" of Wall Street. Barack Obama propagated the myth that through him the US was able to achieve a bloodless revolution leaving intact the power of private property, even as wealth concentration continues more rapidly aided by regressive taxation and the stagnation of wages. To this end, William Domhoff notes that $1 \%$ of US households control $34.6 \%$ of private wealth while the next $19 \%$ of households controls $50.5 \%$ while the $80 \%$ of the US population must make do with $15 \%$ of the nations privately held wealth (2009).

The case as regards racism, too, constitutes subterfuge. In his criticism of Rev. Jeremiah Wright, Obama carefully concedes the existence of racism, though tepidly. At the same time he negated the steadily worsening collective position of African Americans. From Obama's perspective, both Black anger and the demand for affirmative action are unjustified since his very running for the highest office evinces of equality of opportunity (which says nothing of condition). If the latter is correct, the Barack Obama's self-presentation as the quintessential post-racial man and his representation of the US as a post-racial society requires closer inspection. 


\section{Postmodern Man or Teflon Man: Or Why Race Doesn't Stick to Him}

One variant of postmodernism extols the fluidity and hybridity of identity. This stance has the limitation of being co-opted by the power structure as well as enabling obfuscation. Obama demonstrates this capacity by positioning his biography and political ontology in the nexus of a variety of ambiguity generating polarities:

I am the son of a black man from Kenya and a white woman from Kansas. I was raised with the help of a white grandfather who survived a Depression to serve in Patton's Army during World War II and a white grandmother who worked on a bomber assembly line at Fort Leavenworth while he was overseas. I've gone to some of the best schools in America and lived in one of the world's poorest nations. I am married to a black American who carries within her the blood of slaves and slave owners - an inheritance we pass on to our two precious daughters. I have brothers, sisters, nieces, nephews, uncles and cousins, of every race and every hue, scattered across three continents, and for as long as I live, I will never forget that in no other country on Earth is my story even possible (Ibid).

While he claims these biographical facts make him an unconventional Presidential candidate, an admission that undermines his cheeriness about racial progress, others were less coy about what it means to be a post-racial presidential candidate. Upon his election the Wall Street Journal 
appreciated Obama's biography, among a stream of other "firsts", as having special meaning for the death of the struggle for racial justice in the US:

While Obama lost among white voters, as most modern Democrats do, his success is due in part to the fact that he also muted any politics of racial grievance. We have had in recent years two black Secretaries of State, black CEOs of our largest corporations, black Governors and Generals -- and now we will have a President. One promise of his victory is that perhaps we can put to rest the myth of racism as a barrier to achievement in this splendid country. Obama has a special obligation to help do so (Wall Street Journal, 2008).

Recall as I noted earlier that Obama never gained more than $43 \%$ of the White vote nationally: a fact that belies the post-racism thesis. During the 2008 campaign, a concerted effort was made to correlate Obama's post-racial ethos with that of a White US that had transcended racism. Frank Rich for example, suggested the racist appeals of McCain-Palin (and Hillary Clinton) to 'Joe White America', fatefully ignores that "white Americans are not remotely the bigots the G.O.P. would have us believe. Just because a campaign trades in racism doesn't mean that the country is racist. It's past time to come to the unfairly maligned white America's defense" (Rich, 2009). So palpable was the belief that White Americans were past racism, it was argued that "Just as John F. Kennedy was only incidentally a Catholic, so is Obama only incidentally a black man. It is not just that he is post-racial; so is the nation he is generationally primed to lead" (Cohen, 2008). On first appearance, exit polls show that the number of White voters for Obama increased in some 
states thus seeming to confirm the notion of White racial transcendence. But, it is noted that despite improved confidence from White voters in some states the chief guarantee for his win in those states was that the strong African American voter turnout (Franklin, 2008). ${ }^{13}$

Curiously, where the Democrats made gains in White voter turnout in traditional Republican states: Indiana (34\% to $45 \%$ ), Kansas (34\% to $40 \%$ ), Montana (39\% to $45 \%$ ) and North Dakota (35\% to $42 \%$ ), they managed to win only one of the four states (ibid). But where "gains" in the White vote still required substantial African American voter turnout, it is vital to note also in the traditional Southern Republican states, where White Democratic support was low to begin with, the drop was precipitous in some instances: Mississippi (14\% to 11\%), Alabama ( $19 \%$ to $10 \%$ ) Louisiana (24\% to $14 \%$ ) (Ibid). Despite the claims of Obama and his boosters, the foregoing evidence is contrary to the idea that the US is post-racial. Yet, if the US is beyond race and racism because a man of African descent ran and was elected to presidential office, then certainly we are witness to "the end of black politics" (Bai, 2008). This assumes, of course, that

\footnotetext{
${ }^{13}$ States that fell in this category are: North Carolina (27\% to $\left.35 \%\right)$, Virginia (32\% to $39 \%$ ).
} 
Obama ever represented the aspirations of African Americans. ${ }^{14}$ Moreover, it is implied by its absence that the norm of White politics will continue. In the final analysis, it seems that where Barack Obama, has been convincing to White liberals and conservatives alike, his success arose from positioning himself between complex solitudes in a way that subverts African American moral claims while affirming a preferred White narrative of the nation that erases hegemonic white supremacy.

\section{On the Hidden Benefits of Whiteness}

If Barack Obama chose a narrative of the nation that affirmed hegemonic white supremacy, a consequence was an erasure of the ways that White privilege is and was sustained by the state. In this, he carefully navigated the belief, for a variety of reasons, some of which are addressed above, that African Americans are undeserving while Whites work hard for what they have. He did so by adeptly recognizing that Reverend Wright, like his white grandfather, fought in the imperial adventure of World War II to serve the US. This reflection must be seen in one instance as a sop to African American military personnel inasmuch as it aims to negate that such

\footnotetext{
${ }^{14}$ In November 2007, a coalition of African American activists marched on the White House. Their demands, indicating that the Black interest is in fact an inclusive social agenda of decolonization, anti-imperialism and socialism, were for an end to imperial adventures and serious public policy response to mass poverty and inequality. As one activist put it, "We recognize that Barack Hussein Obama is white power in black face" (AFP, 2009). The question of Obama's relationship to African Americans was raised as early as 2004 and rearticulated in his 2008 presidential campaign with regard to his opposition to slavery reparations (Huffington Post, 2008). It is therefore baseless to suggest that Obama's presidency in any way positively influenced the decision of the US Senate to vote unanimously for a state apology for slavery sponsored by Iowa Democratic Senator Tom Harkin (Thompson, 2009). Interestingly, for over two decades, Michigan Democratic Representative John Conyers has repeatedly put forward a Bill to Senate to study and make preparations for slavery and intergenerational racial discrimination - without success (see N'COBRA.ORG, 2009). So, it seems the apology delinked from the prospect of meaningful reorganization in equality of condition aims, like the 1787 Constitution, to defer addressing racial justice.
} 
soldiers were and will continue to be confronted with white supremacist social exclusion once of out uniform. The off-handed reference to Wright and others doing well for themselves despite facing "discrimination" (Obama, 2008), fails to appreciate the active role the state played in frustrating and denying benefits to African American veterans. While there is no doubt Obama's White grandfather and mother served and worked in various capacities to support the US war effort, this fact, however, does not obviate the fact of state racial preferences for White GI's and their families. This inconvenient truth belies Obama's anti-affirmative action rhetoric and the irony that he is a beneficiary of unearned White privilege. By congratulating the likes of Wright for achieving their piece of the American pie despite great odds (a sign there was progress) and failing to disclose that many Whites like his grandparents were beneficiaries of government largesse, Obama reframes affirmative action, as most Whites do, as a distortion of the principle of juridical equality. This proposition effectively denies what was and is an on-going reality: that unless the state defends the interests of disempowered numerical "minority" groups, numerical democracy becomes a civil totalitarian regime that permanently stands against disempowered numerical 'minorities' (see Martinot, 2004, pp. 3-4).

The historical evidence acquits Reverend Right, unmasks Obama’s self-implication in White privilege, even as it reveals that Obama's assent to White "resentment" (Obama, 2008) is disingenuous. Karen Brodkin, notes that:

[t]he GI Bill of Rights, as the 1944 Serviceman's Readjustment Act was known, was arguably the most massive affirmative action program in U.S. history...The 
GI benefits ultimately extended to sixteen million GIs (veterans of the Korean War as well) including priority in jobs - that is, preferential hiring, but no one objected then; financial support during the job search; small loans for starting up businesses; and, most important, low interest home loans and educational benefits, which included tuition and living expenses. This legislation was rightly regarded as one of the most revolutionary postwar programs. I call it affirmative action because it was aimed at and disproportionately helped male, Euro-origin GIs... (1998, p. 123).

The White assault against affirmative action, then, must be read as the effort of the White working classes to arrogate for itself as much of the economic pie that is available to them under the conditions of capitalism. The evidence neither supports Obama's acquiescence nor White angst about affirmative action inasmuch as the original GI Bill was a massive state entitlement that largely benefited Whites. Tactically, after its official inauguration by President Kennedy in the face of post-'World War II' war economic expansion, Whites have claimed affirmative action to be an unfair concession to African Americans. The reality is, however, that White people in general but White women in particular have been the chief beneficiaries of affirmative action (Kelly, 1996; Bell, 1992). Indeed, Jet Magazine cites a New York Times/CBS poll that found "most [White] Americans object to Blacks being given preferences in jobs and college admission, but didn't mind the advantages being given to white women" (1995). As Eric Foner (2003) points out, he is dismayed that the so-called debate about affirmative action should be a 
wedge that divides Americans when all along, and it continues to be the case, that White men are perfectly comfortable with the assumption their 'just desserts', for being White men, arouses neither self-doubt nor suspicion as to their abilities. In sum, with the expansion of the post-war economy and the accruing of affirmative action benefits going to White women, Whites and antiaffirmative action politicians have achieved a massive deception that blames African Americans for the decay of 'equality' in the US. And it is this why, finally, I think Barack Obama crafted his assent to White reaction against affirmative action. In order to convince White America he is competent to be their president. In view of what W. E. B. Dubois called this "unforgivable thing of blackness" he had to strategically distance himself from a social construction of blackness which presumes intellectual inferiority, sloth, dependence on state largesse and above all a radical politics for racial and social justice.

\section{Conclusion}

This essay expresses ideas that may be, borrowing from Barack Obama's strangely prudish phraseology, 'impolite for decent company'. The words and ideas of Barack Obama and my rendition of US social history have been the groundwork for a severe critique of his deployment of race in relation to his political ontology. Coming from a Northern neighbor, some might say the ideas expressed herein are unfair, unfriendly, and, unwelcome. But, if Bill Clinton or George Bush were the objects of a similarly rigorous critique, would this impression ever arise? In a strange way, their whiteness, because it would not be the basis for a celebration of 
their Presidency, would not permit their personal accomplishments to be regarded as a transcendence of their nation's racial malaise. Whiteness, let us remember, need not be explained; excellence is the assumed the norm. But, what becomes of our critical faculties and our capacity to analyze the discourse of political leaders when the dominant criteria for excellence fixate on their accomplishments as charismatic personalities and transcendence of their race? If a Black politician in a normatively white supremacist nation both draws upon and plays off White racism to manipulate vote-getting, the greater the harm that is done to the Black people of whom he is a "member" and ever more will White racism be deepened. Is this a racial manicheanism in which a President of African descent cannot be genuinely elected to the white house on the content of his character rather than the colour of his skin?

The election of Barack Obama, far from reducing the significance of race has made the need for conversation on the continued significance of the 'colour line' all the more urgent. The words of Derrick Bell can be taken to suggest the colour of the President, as far as African Americans are concerned, will not substitute for an active anti-racist politics:

Black people will never gain full equality in this country. Even those herculean efforts we hail as successful will produce no more than temporary 'peaks of progress, 'short-lived victories that slide into irrelevance as racial patterns adapt in ways that maintain white dominance. This is a hard-to-accept fact that all history verifies. We must acknowledge it, not as a sign of submission, but as an act of ultimate defiance [italics in original] (1992, p. 12). 


\section{References}

Abella, A. (2008). Soldiers of Reason: The RAND Corporation and the rise of the American empire. New York: Harcourt, Inc.

Adams, J. (1984). The Unnatural Alliance: Israel and South Africa. London: Quartet Books.

AFP. (2009). African-Americans slam Obama in White House protest. Retrieved December 7 , 2009. http://www.google.com/hostednews/afp/article/ALeqM5hQPy9x3dKK0YOBQ3crtDlhOp8xA

Ani, M. (1994). Yurugu: An African Centered Critique of European Cultural Thought and Behavior. Trenton, New Jersey: African World Press, Inc.

Aristotle. Translated by Ernest Barker. (1958). The Politics of Aristotle. New York: Oxford University Press.

Armour, J. D. (1994). Race Ipsa Loquitur: Of Reasonable Racists, Intelligent Bayesians, and Involuntary Negrophobes. Stanford Law Review, 46(4 ), 781-816.

Baker, H. A. (2008). Betrayal: How Black intellectuals have abandoned the ideals of the Civil Rights era. New York: Columbia University Press.

Bai, M. (2008). Is Obama the End of Black Politics? Retrieved December 7, 2009. http://www.nytimes.com/2008/08/10/magazine/10politics-t.html?pagewanted=print

Bell, D. (1992). Faces at the Bottom of the Well. New York, NY: BasicBooks.

Bolton, K Jr., and J. R. Feagin. (2004). Black in Blue: African American Police Officers and racism. New York: Routledge.

Bonger, W. (1969). Race and Crime. Translated from the Dutch by Margaret Mathews Hordyk. Montclair, New Jersey: Patterson Smith.

Bowles, W. (2009). Barack Obama, Front Man for the 'Man'. Creative-i.info. Retrieved October 23, 2009 from http://www.creative-i.info/?p=9944

Brenner, L. (1983). Zionism in the Age of the Dictators. Lawrence Hill and Co. 
Brodkin, K. (1998). How Jews Became White Folks and What That Says About Race in America. New Brunswick, N.J.: Rutgers University Press.

Butler, J. 2008. “Uncritical Exuberance?”. Retrieved May 27, 2009. http://www.indybay.org/newsitems/2008/11/05/18549195.php

CNN. (2008). Exit Poll. Retrieved August 20, 2009. http://www.cnn.com/ELECTION/2008/results/polls/\#USP00p1

Cose, E. 1993. Rage of a Privileged Class. Harper/Collins. New York.

Cohen, R. 2008. The Election That LBJ Won”. Retrieved December 7, 2009. http://www.washingtonpost.com/wpdyn/content/article/2008/11/03/AR2008110302609.html

Cox, O. 1970. Caste, class, \& race: a study in social dynamics. New York: London: Modern Reader Paperbacks.

Daily Mail. 2009. Afghan president demands an end to air raids on Taliban amid claims of 130 civilian deaths. Retrieved October 22, 2009. http://www.dailymail.co.uk/news/worldnews/article-1180171/Afghan-presidentdemands-end-air-raids-Taliban-amid-claims-130-civilian-deaths.html

Darden, J. T. 2004. The Significance of White Supremacy in the Canadian Metropolis of Toronto. Lewiston: The Edwin Mellen Press.

Davidson, B. Africa in History. London: Paladin.

Debusmann, B. 2009. In American crisis, anger and guns. Retrieved March 19, 2009. http://blogs.reuters.com/great-debate/2009/03/19/in-american-crisis-anger-and-guns/

Deliovsky, K. (2010). White Femininity: Race, gender and power. Black Point, Nova Scotia. Fernwood Publishing.

Dyer, R. 1997. White. New York: Routledge.

Domhoff, W. (2009). Wealth Income and Power. WhoRulesAmerica.net. Retrieved December 30, 2009. http://sociology.ucsc.edu/whorulesamerica/power/wealth.html 
Du Bois, W. E. B. (1899). The Philadelphia Negro: a social study: Together with a special report on domestic service by Isabel Eaton. Philadelphia: Published for the University.

Duster, T. (2001). The "Morphing" Properties of Whiteness. In Birgit Brander Rasmussen, Erick Klinenberg, Irene J. Nexica, and Matt Wray (eds.), The Making and Unmaking of Whiteness. Durham, NC; London: Duke University Press.

Ehrenstein, D. (2007). Obama the 'Magic Negro': The Illinois senator lends himself to white America's idealized, less-than-real black man. Retrieved Dec. 29, 2008. http://www.latimes.com/news/opinion/la-oe-ehrenstein19mar19,0,5335087.story?coll=laopinion-center

Eibach, R. P., Purdie-Vaughns, Valerie. (2009). Change we can believe in? Barack Obama's framing strategy for bridging racial divisions. Du Bois Review, 6(1), 137-151.

Eyre, P. (2009). The Deceit of Depleted Uranium Use in Afghanistan: Part 1 - The Vital Evidence. Retrieved October 22, 2009. http://www.paltelegraph.com/opinions/editorials/2611-the-deceit-of-depleted-uraniumuse-in-afghanistan-part-1 2009. The Deceit of Depleted Uranium Use in Afghanistan: Part 2 - The Vital Evidence. Retrieved October 22, 2009. http://www.paltelegraph.com/opinions/editorials/2674-thedeceit-of-depleted-uranium-use-in-afghanistan-part-2-the-vital-evidence

Eze, E. C. (1995). The Colour of Reason: The idea of "race" in Kant's anthropology. In Katherine Faull (ed.), Anthropology and the German Enlightenment: Perspectives on Humanity. Lewisburg [Pa.]: Bucknell University Press; London; Toronto: Associated University Presses.

Fanon, F. (1967). Black Skin, White Masks. New York: Grove Press, Inc.

Foner, E. (2003). In Cooper Thompson, Emmett Schaefer, and Harry Brod (Eds.), White men challenging racism: 35 personal stories. Durham : Duke University Press.

Ford, R. T. (2009). Barack is the New Black: Obama and the promise/threat of the post-civil rights era. Du Bois Review, 6(1), 37-48.

Franklin, C. (2008). "White Vote for Obama, Part 2". Retrieved December 7, 2009. http://www.pollster.com/blogs/white_vote_for_obama_in_the_st_1.php 
Fukuyama, F. (1989). 'The End of History'. National Interest. Number 16. Retrieved on December 28, 2009.

http://www.unc.edu/ rlstev/Text/Fukuyama\%20End\%20of\%20History.pdf

Gardner, D. (2008). 'Most shelter dogs are mutts like me': Obama defies political correctness at first press conference. Retrieved December 5, 2009. http://www.dailymail.co.uk/news/worldnews/article-1084007/Most-shelter-dogs-muttslike-Obama-defies-political-correctness-press-conference.html

Garland, D. (1987). Punishment and Welfare: A history of penal strategies. Aldershot, Hants, England; Brookfield, VT: Gower.

Green, R. M. (1951). A Translation of Galen's Hygiene. Springfield, Ill.: Charles C. Thomas.

Greenlee, S. (2002). The Spook Who Sat by the Door. Toronto: Scholarly Book Services Inc.

Gould, S. J. (1981). The Mismeasure of Man. New York: W. W. Norton and Company.

Hacker, A. (2008). Obama: The Price of Being Black. 55(14): SEPTEMBER 25, 2008.

Retrieved May 27, 2009. http://www.nybooks.com/articles/21771

Haynes, D. V. (2009). Blacks hit hard by economy's punch. Retrieved December 6, 2009. http://www.washingtonpost.com/wpdyn/content/article/2009/11/23/AR2009112304092.html

Holmes, E. (2009). StratCom commander: New nukes needed. Retrieved December 12, 2009.http://www.airforcetimes.com/news/2009/11/airforce_chilton_111909w/

Huffington Post. (2008). Obama Opposes Slavery Reparations. Retrieved December 8, 2009. http://www.huffingtonpost.com/2008/08/02/obama-opposes-slavery-rep_n_116506.html

Hutchinson, E. O. (1996). The Assassination of the Black Male Image. New York: Simon and Schuster.

Jacobson, M. F. (1999). Whiteness of a Different Color: European immigrants and the alchemy of race. Cambridge Mass.: Harvard University Press.

Jet Magazine. (1995). Who benefits most from affirmative action? Retrieved December 30, 2009. http://findarticles.com/p/articles/mi_m1355/is_n19_v87/ai_16717080/ 
Jhally, S. (1992). "Enlightened" Racism: The Cosby show, audiences, and the myth of the American dream. Boulder: Westview Press.

Jones, T. (1977). The Police in America: A Black viewpoint. The Black Scholar.

Jordan, W. (1977). White Over Black: American attitudes toward the Negro, 1550-1812. New York: W. W. Norton and Company.

Katz, W. L. (1986). Black Indians: A Hidden Heritage. New York, Atheneum.

Kelly, J. (1996). Who Benefits from Affirmative Action? Whites are key beneficiaries of special admission standards at Washington State. Black Issues in Higher Education. Retrieved December 30, 2009. http://findarticles.com/p/articles/mi_m0DXK/is_n7_v13/ai_20899751/

Kissinger, H. (1974). National Security Study Memorandum NSSM 200: Implications of Worldwide Population Growth For U.S. Security and Overseas Interests. (THE KISSINGER REPORT). Retrieved December 4, 2009. http://www.population-security.org/28-APP2B.html\#II

Klein, N. (2008). The Shock Doctrine: The rise of disaster capitalism. Canada: Vintage Canada/Random House Canada.

Kuhnhenn, J. (2007). Obama taps Wall Street for dollars. Retrieved November 29, 2009. http://www.usatoday.com/news/topstories/2007-07-16-1571558437_x.htm

Lutz, C. (2009). Obama's Empire. Newstatesman.com. Retrieved 10/23/09. http://www.newstatesman.com/asia/2009/07/military-bases-world-war-iraq

Mandel, M. (1994). The Charter of Rights and the Legalization of Politics in Canada. Toronto: Thompson Educational Publishing, Inc.

Mann, C. (1995). The Contribution of Institutionalized Racism to Minority Crime. In Darnell F. Hawkins (ed.), Ethnicity, Race, and Crime: Perspectives across time and place. New York: State University of New York Press.

Martinot, S. (2003). The Rule of Racialization: Class, identity, governance. Philadelphia: Temple University Press. 
Mepham, J. (1979). The Theory of Ideology in Capital. In John Mepham and David-Hillel Rubin (eds.), Issues in Marxist Philosophy. Vol III. Epistemology, Science, Ideology. Brighton: The Harvester Press.

McHugh, G. A. (1978). Christian Faith and Criminal Justice: Toward a Christian response to crime and punishment. New York: Paulist Press.

Mills, C. W. (2006). Modernity, Persons, and Subpersons. In Joseph Young and Jana Evans Braziel (eds.), Race and the Foundations of Knowledge: Cultural amnesia in the academy. Urbana and Chicago: University of Illinois Press.

(2003). From Class to Race: Essays in White Marxism and Black Radicalism. New York: Rowman and Littlefield Publishers, Inc.MSNBC.COM. 2009. White House disputes Carter's analysis. Retrieved October 23, 2009. http://www.msnbc.msn.com/id/32869276/ns/politics-capitol_hill

Muhammad, D., and Ehrenreich, B. (2009). The Destruction of the Black Middle Class. From Recession to Depression. Retrieved November 23, 2009. http://www.counterpunch.com/muhammad08052009.html

National Coalition of Blacks for Reparations in America (N'COBRA). (2009). Retrieved December 8, 2009. http://www.ncobra.org/comm.htm

Novick, M. (2008). Obama, Imperialism and the Paradox of Plenty amid Poverty. Turning the Tide: Journal of Anti-Racist Action, Research \& Education. Retrieved December 9, 2009. http://academic.udayton.edu/race/2008ElectionandRacism/obama/obama93.htm

Obama, B. (2009). Text of President Barack Obama's speech, provided by the White House, as delivered to the Ghanaian parliament today in Accra, Ghana. Retrieved November 3, 2009. http://www.cbsnews.com/stories/2009/07/11/politics/main5152235.shtml (2008). Barack Obama's speech on race. The Black Commentator. Retrieved December 28, 2009. http://www.blackcommentator.com/269/269_obama_speech_race.html . (2004). Dreams of My Father: A story of race and inheritance. New York: Three Rivers Press. 
Offen, N. 2009. Hersh: Military waging war with White House. Heraldsun.com. Retrieved 10/23/09. http://www.heraldsun.com/pages/full_story/push?article-Hersh+Military+waging+war+with+White+House\%20\&id=3974209-Hersh+Military+waging+war+with+White+House\&instance=homethirdleft noffen@heraldsun.com; 419-6646

Pager, D. (2007). Race, Crime, and Finding Work in an Era of Mass Incarceration. Chicago: The University of Chicago Press.

Parker, C., Sawyer, M. Q., and Towler, C. (2009). Du Bois Review, 6(1), 193-217.

Parry, R. (2009). Colin Powell and Lessons of My Lai. Retrieved December 8, 2009. http://www.consortiumnews.com/2009/090409.html

Peery, D,. and Bodenhausen, G. V. (2009). Du Bois Review, 6(1), 71-82.

Pettigrew, T. F. (2009). Post-racism?: Putting President Obama's victory in perspective. Du Bois Review, 6(2), 279-292.

Piven, F. F. and Cloward, R. (1993). Regulating the Poor: The functions of public welfare. New York: Vintage Books.

Piven, F. F. (1976). The Social Structuring of Political Protest. Politics \& Society, 6(3): 297-326.

Poliakov, L. (1974). The Aryan Myth: A history of racist and nationalist ideas in Europe. London: Chatto and Heinemann for Sussex University Press.

Rafky, D. M. 1975. Racial Discrimination in Urban Police Departments. Crime and Delinquency, 21, 233-242.

RAND Corporation. (2009). Increasing Participation in No Child Left Behind School Choice. Retrieved May 28, 2009.

http://www.rand.org/pubs/research_briefs/2009/RAND_RB9424.pdf

Rich, F. 2008. In Defense of White Americans. Retrieved December 7, 2009. http://www.nytimes.com/2008/10/26/opinion/26rich.html?_r=1\&hp 
Rifkin, J. 2004. The End of Work: The decline of global labor force and the dawn of the post-market era. New York: Jeremy P.Tarcher/Penguin.

Rivera, A., Huezo, J., Kasica, K., and Muhammad, D. (2009). State of the Dream: Silent Depression. Retrieved February 16, 2009. http://www.ips-dc.org/reports/state_of_the_dream_2009

Roberts, D. (1992-1993). Crime, Race, and Reproduction. Tulane Law Review, 67, 19451977.

Rome, D. 2004. Black Demons: The media's depiction of African American male criminal stereotype. Westport, Conn.: Praeger.

Royster, D. 2003. Race and the invisible hand : how white networks exclude black men from blue-collar jobs. Berkeley: University of California Press.

Rousseau, M., and Houdart, O. 2007. Should 'U.S. Americans' Instead Call Themselves 'United Statesians?'. Le Monde, France. Retrieved December 8, 2009. http://www.watchingamerica.com/lemonde0000146.shtml

Russell, K. K. 1998. The Colour of Crime: Racial hoaxes, white fear, black protectionism, racial harassment, and other macroaggressions. New York: New York University Press.

Santos, J. 2008. Barack Obama and the "end of racism". The-Fourth-World-Blogspot.com. Retrieved November 22, 2009.http://the-fourth-world.blogspot.com/2008/02/barackobama-and-end-of-racism.html

Sellin, T. 1935. Race Prejudice in the Administration of Justice. The American Journal of Sociology, 41(2), 212-217.

Sherwin-White, A. N. (1967). Racial prejudice in Imperial Rome. Cambridge: University Press.

Siegel, R. (1968). Galen's System of Physiology and Medicine: An analysis of his doctrines and observations on blood flow, respiration and humors. Basel: S. Krager.

Simon-Aaron, C. (2008). The Atlantic Slave Trade, Empire, Enlightenment, and the Cult of the Unthinking Negro. Lewiston, New York: The Edwin Mellen Press.

Singh, G. B., and Watson, T. (2009). Ghandi Under Cross-Examination. Lathrop, USA: Sovereign Star Publishing. 
Smith, M. 2004. Radicalism of the Left and Right are equally deplorable: The 'golden mean' prejudice. In Judith C. Blackwell, Murray Smith and John Sorenson (eds.), Culture of Prejudice: Arguments in social science. Peterborough, Ontario: Broadview Press.

Spartacus Educational. 2009. Le Duc Tho Biography. Retrieved December 4, 2009. http://www.spartacus.schoolnet.co.uk/VNtho.htm

Spitzer, E. (2009). Eliot Spitzer: Geithner, Bernanke 'Complicit' in Financial Crisis and Should Go. Retrieved December 4, 2009.

http://www.democracynow.org/2009/12/4/eliot_spitzer_geithner_bernanke_complicit_in

Stabile, C. A. (2006). White Victims, Black Villains: Gender, race, and crime news in US culture. New York: Routledge.

Staples B. (2009a). Savoring the Undertones and Lingering Subtleties of Obama's Victory Speech. New York Times. Retrieved December 29, 2009. http://theboard.blogs.nytimes.com/2008/11/07/savoring-the-undertones-and-lingeringsubtleties-of-obamas-victory-speech/

. (2009b). Obama's Victory Speech: A Response to Comments. New York Times. Retrieved December 29, 2009. http://theboard.blogs.nytimes.com/2008/11/10/obamasvictory-speech-a-response-to-comments/

Sutherland, E. H., Revised by Donald R. Cressey. (1955). Principles of Criminology, $5^{\text {th }}$ ed. Chicago, Philadelphia, New York: J. B. Lippincott Company.

Tainter, J. A. (2009). The Collapse of Complex Societies. Cambridge: Cambridge University Press.

Teichrib, C. (2009). A Leadership Review of the Barack Obama Administration. The August Review. Global Elite Research Centre. Retrieved May 28, 2009. http://www.infowars.com/a-leadership-review-of-the-barack-obama-administration/

The Guardian Civic League Inc., et al., v. Philadelphia Police Department et al. 2009. Retrieved September 1, 2009. http://www.whyy.org/news/itsourcity/complaint.pdf

Wall Street Journal. (2008). President-Elect Obama: The voters rebuke Republicans for economic failure. Retrieved December 7, 2009. http://online.wsj.com/article/SB122586244657800863.html 
Willhelm, S. (1994).The Economic Demise of Blacks in America: A prelude to genocide? In David Baker (ed.), Reading Racism and the Criminal Justice System. Toronto: Canadian Scholars Press.

. (1983). Black in a White America. Cambridge, Mass.: Schenckman Publishing Company, Inc.

. (1980). Can Marxism Explain America’s Racism. Social Problems, 28(2), 98-112.

. (1970). Who Needs the Negro? Cambridge, M.A.: Schenckman.

Wilson, W. J. (1978). The Declining Significance of Race: Blacks and changing American institutions. Chicago: University of Chicago Press.

(1983). The Truly Disadvantaged: The inner city, the underclass, and public policy. Chicago: University of Chicago Press.

Williams, P. 1994. Spirit-murdering the messenger: The discourse of finger pointing as the law's response to racism. In David Baker (ed.), Reading Racism and the Criminal Justice System. Toronto: Canadian Scholar's Press.

Winant, H. (2001). The World is a Ghetto: Race and democracy since World War II. New York: Basic Books.

Wise, T. (2009). Between Barack and a Hard Place: Racism and white denial in the age of Obama. San Francisco: City Lights Books/Open Media Series.

Wright, K. (2009). If They Are So Scared, How Come We're The Dead Ones?. Retrieved June 15, 2009. http://www.theroot.com/views/if-they-are-so-scared-how-come-weredead-ones 